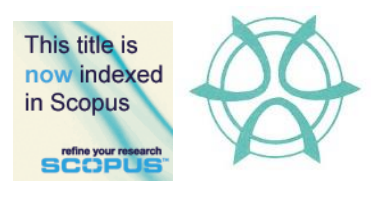

\title{
PERCEPTUAL STUDY ON CONVENTIONAL QUALITY OF LIFE INDICATORS
}

\author{
Noor Suzilawati Rabe', Mariana Mohamed Osman ${ }^{2}$, Syahriah Bachok ${ }^{3}$, Nur \\ Farhanah Rosli ${ }^{4}, \&$ Muhammad Faris Abdullah ${ }^{5}$ \\ 1,2,3,4,5 Kulliyyah of Architecture and Environmental Design \\ INTERNATIONAL ISLAMIC UNIVERSITY MALAYSIA
}

\begin{abstract}
Quality of life (QOL) is both individual and collective attributes. Quality of life should encompass both objective and subjective measures whilst promoting for balance in every aspect of human existence. The objective of this study is to assess the QOL of the population in Malaysia by using Selangor as a case study. 600 samples from four districts in Selangor were selected through random sampling method. From literature review, 9 main components of QOL were identified and included in questionnaire form. Relative importance index (RII) equation was then used to report on the analysis of QOL components. Results from the survey indicated that majority of the respondents were likely to perceive QOL components as moderate and highly satisfied. Overall, respondents claimed that they were satisfied and enjoying their lives and at the same time satisfied with their current quality of life. The results indirectly show that each of QOL component was interrelated with each other in creating the satisfaction on quality of life of the people. This is in line with the findings on the three basic human relationships with Allah SWT, with other human and with nature in protecting their faith ( $\mathrm{din})$, human self (nafs), intellect ( $a q l)$, posterity (nasl) and wealth (mal) through establishing justice, eliminating prejudice and alleviating hardship by promoting good and preventing harm to self and others.
\end{abstract}

Keyword: Quality of life, maqasid al-shariah, population well-being. 
Noor Suzilawati Rabe, Mariana Mohamed Osman, Syahriah Bachok, Nur Farhanah, \& Mohammad Faris Abdullah

Perceptual Study on Conventional Quality of Life Indicators

\section{QUALITY OF LIFE INDICATORS}

Improving the quality of life (QOL) of the citizen has always been the main focus of the Malaysian government and it has been one of the main agendas in the 11th Malaysia Plan 2016-2020. Generally, QOL is about the extent to which human needs are fulfilled in relation to their perception of subjective wellbeing. Thus, it is the role of policy makers and professionals to provide opportunities for the people to be able to meet their desired well-being (Costanza et al., 2005).

The World Health Organization Quality of Life group defines QOL as 'individual's perception of their position in life in the context of the culture and value systems in which they live and in relation to their goals, expectations, standards and concerns' (Phillips, 2006, p.23). Similarly, several authors (Zainal, Kaur, Ahmad, \& Khalili, 2012; Gilgeous, 1998) see QOL as the satisfaction of people over various dimensions including material, education, security, physical and living environment that affected by their perception on what they refer as ideal life.

Worldwide, QOL is the subject of academic debate in various fields particularly in economics, field of happiness studies, a research area shared with psychologists and sociologists (Costanza et al., 2005). Moreover, the discussion on QOL also become increasingly popular over the past two decades in the area of education, security as well as in fulfilment of enjoyment of the aesthetic and spiritual needs (Pajaziti, 2014; Omar, 2009). Yet, the measurement of QOL varies and depend neither on the subjective experience of people nor on the fulfilment of their wishes (Yahya \& Selvaratnam, 2015; Diener, Suh, Lucas, \& Smith, 1999).

In Malaysia, numerous studies (Idris et al, 2016; Mohit, 2014; Ibrahim et al., 2013) have been conducted to measure the QOL of the population. Several authors concur that QOL is one of the biggest challenges to government especially to reduce gap that exists between various groups and communities in the country (Idris et al., 2016). Meanwhile, other studies found quality of life has increased positively with improvement in environment, including physical and natural surroundings, education, health status, age, culture, safety as well as economic development level (Yassin et al., 2012; Skevington, 2010). Yet, progress on human well-being and development has bypassed groups, communities or societies, resulting in the problem of human deprivations to persist (UNDP, 2016).

Quality of life is both an individual and collective attribute (Phillips, 2006), in which adequate and suitable tool to measure the quality of life is still inadequate (Mohamad et al., 2014). Empirical research on quality of life have been emphasising on material well-being, without the association of spiritual and non-material aspect of life. This has been proven to provide negative or decline in subjective well-being of population (Chapra, 1993). 
PLANNING MALAYSIA

Journal of the Malaysia Institute of Planners (2018)

The well-being of Malaysian has been annually measured in Malaysia Quality of Life Index (MQLI) from 1999 to 2011. Since 2012, this has been replaced by Malaysia Well-Being Index (MWI). The MQLI included 38 indicators categorized under 11 components of QOL. However, the new MWI expanded to include 14 components of well-being to represent economic and social well-being of Malaysia. The components under economic well-being are transportation, communication, education, income distribution and working life. Meanwhile, components of social well-being are housing, leisure, governance, public safety, social participation, culture, health and environment. As shown in Table 1 below, the measure of well-being representing the quality of life for population in Malaysia are quantifiable and driven by objective measurement.

Table 1: MWI 2000-2012

\begin{tabular}{lcccc}
\hline \multirow{2}{*}{ MWI Component } & \multicolumn{4}{c}{ Index } \\
\cline { 2 - 5 } Economic well-being & $\mathbf{2 0 0 0}$ & $\mathbf{2 0 1 0}$ & $\mathbf{2 0 1 2}$ & $\mathbf{2 0 0 0}$ - 2012 \\
\hline Transport & 100 & 126.3 & 136.9 & 36.9 \\
Communications & 100 & 120.6 & 136.2 & 36.2 \\
Education & 100 & 128.6 & 132.9 & 32.9 \\
Income and distribution & 100 & 124.2 & 131.8 & 31.8 \\
Working Life & 100 & 121.5 & 128.6 & 28.6 \\
\hline Social well-being & & $\mathbf{1 1 7 . 2}$ & $\mathbf{1 2 1 . 0}$ & $\mathbf{2 1}$ \\
\hline Housing & 100 & 137 & 136.9 & 36.9 \\
Leisure & 100 & 126.1 & 131.4 & 31.4 \\
Governance & 100 & 122.6 & 128.1 & 28.1 \\
Public Safety & 100 & 116.2 & 125.6 & 25.6 \\
Social Participation & 100 & 110.6 & 120.6 & 20.6 \\
Culture & 100 & 117.6 & 120.3 & 20.3 \\
Health & 100 & 110.3 & 114.1 & 14.1 \\
Environment & 100 & 106.9 & 107.3 & 7.3 \\
Family & 100 & 107.3 & 104.6 & 4.6 \\
\hline Source: & & & & \\
\hline
\end{tabular}

Source: EPU, 2013

Note: Base Year: 100

However, as discussed by numerous authors (Pajaziti, 2014; Noll, 2002), quality of life should encompass both objective and subjective measures. This is in line with the objectives of the shariah or the maqasid al-shariah, which is to promote the well-being of all mankind through protection on faith (din), human self (nafs), intellect ( $a q l)$, posterity ( $\mathrm{nasl}$ ) and wealth ( $\mathrm{mal}$ ) through establishing justice, eliminating prejudice and alleviating hardship by promoting good and 
Noor Suzilawati Rabe, Mariana Mohamed Osman, Syahriah Bachok, Nur Farhanah, \& Mohammad Faris Abdullah Perceptual Study on Conventional Quality of Life Indicators

preventing harm to self and others (Syed Ali \& Hassan, 2014; Dusuki \& Abdullah, 2007).

Maqasid al-shariah covers not only the objectives of the divine law (shariah) but also every aspect of human existence including the general wellbeing of every individual. Generally, it provides an outline of "what should" and "should not" be done in Islam (Abdullah \& Furqani, 2012). This is as important as the three basis for Islamic concept as discussed by Hanapi (2015) that emphasised on the relations between humans and Allah SWT as mentioned in Surah al-'Ankabut (29:62-63), Yunus (10:31) and al-Zukhruf (43:87). Those verses specified all Muslim should adhere to the laws of Allah and subscribe to the true teachings of Islam. By obeying Allah SWT, one has to follow His command and not use only emotions as a measure for own actions. In this study context, satisfaction over quality of life can be referred to a good life and success in achieving happiness in life as a Muslim. Therefore, in redefining what measure the quality of life in line to maqasid al-shariah goals, ones have to believe (aqidah) towards Allah SWT as the Creator. Thus, all human are responsible in the fulfilment of the basic needs for all as it is considered the ultimate human rights in Islam.

The second Islamic worldview as mentioned by Hanapi (2015) is the relation among humans. From maqasid al-shariah context, Muslims should abide to high morality not only in their actions, but also in interactions with society and others in protecting the five fundamental aspects of shariah, which are the religion, life, mind, lineage and property. Islam provides an outline for human to interact with each other in full responsibility, trust, morality and ethics in fulfilling our duty as a vicegerent of Allah SWT. Through practice on equitable income distribution among the vulnerable poor to eradicate poverty, provision of material and non-material needs such as freedom, equity for people, excellence in moral, safety and economic capacity for society as a whole, the maqasid alshariah concept can be realized. In principle, Islam obligates promoting social justice and at the same time alleviating poverty which could be channelled through zakah, waqaf, hibah (gift), sadaqah and charity that would encourage the building of a strong bond among community. As elaborated by Yusuf alQaradawi (2011), Islam prohibits extravagance, and ordains moderation and sometimes thrift, thus, helping others is necessary to provide an adequate and suitable standard of living and to help Muslims remain above the poverty level.

The third Islamic worldview concept is the relations between humans and nature. Allah SWT has entrusted human in accordance with their roles as a vicegerent of Allah SWT to harmonise with the world as mentioned in Surah alIsra' (17:70). In referring to the maqasid al-shariah, Muslims are entrusted to manage and utilize the natural resources but bound by the regulations and restrictions determined by Allah SWT. As Wahbah Al-Zuhaily (1994) discusses, maqasid al-shariah focuses on the three goals, which are to achieve goodness 
PLANNING MALAYSIA

Journal of the Malaysia Institute of Planners (2018)

(maslahah), avoid evilness (mafsadah) and remove calamities to mankind in this world and hereafter. Ultimately, Muslims are obligated to avoid from getting involved with dangerous or careless acts that would cause harm to themselves or others.

Islam in principle is concerned with the total well-being of human beings. Consequently, as Malaysia is a country where Muslims make up the majority of the population, the application of shariah law is encouraged. Thus, this indicates there is a need to blend religious aspirations and objectives i.e. the maqasid alshariah on measure of QOL in Malaysia. Hence, the objective of this research is to assess the perception of Malaysian on the conventional QOL indicators by selecting Selangor as a case study for the research and to assess whether the level of QOL is in line with the maqasid al-shariah.

\footnotetext{
ANALYSIS ON QOL INDICATORS: A CASE STUDY OF SELANGOR

Questionnaire survey was selected as method for data collection for the research. Statistical Package for the Social Sciences (SPSS) was used to analyse the quality of life of population involved in the research.
}

\section{Sample}

By using the Yamane (1976) formula, sample size in the study was originally determined at 400 samples and the age range of the respondents should be between 18 to 65 years old. Taking into considering the probability of error and bias in data, the number of target sample was increased to 600 samples. The distribution of sample was focused in four districts namely Petaling Jaya, Sepang, Klang and Gombak, as these districts are considered as the major growth areas for the state of Selangor. Following data screening process, only 500 samples were found to be valid for analysis. The samples are made up of $55.6 \%$ male and 44.4\% female respondents, of which 76.2\% Malay, $12.4 \%$ Chinese and $11.4 \%$ Indian. The samples were equally distributed across income level, whereby $43 \%$ respondents were with income below RM3,000, 32.8\% between RM3,001RM6,000 and 24.2\% earned more than RM6,000 monthly. Additionally, respondents aged below 40 years old made up the majority with $80.8 \%$ of respondents, while rest were aged between 41 to 60 years old $(16.8 \%)$ and more than 60 years old $(2.4 \%)$. Over half of the respondents $(56.8 \%)$ had secondary education, while the remaining of $43.2 \%$ had higher education.

\section{Measure}

Questionnaire survey was conducted to collect primary data on QOL from target respondents. 9 QOL components consisting of several items to measure QOL of population in Malaysia drawn from various literature reviews were used in the questionnaire and measured by 10 scores, 0 as 'Don't know' until 10 as the highest score representing 'Extremely satisfied'. The Relative Importance Index 
Noor Suzilawati Rabe, Mariana Mohamed Osman, Syahriah Bachok, Nur Farhanah, \& Mohammad Faris Abdullah Perceptual Study on Conventional Quality of Life Indicators

(RII) analysis was undertaken to determine the rank of items from each QOL component perceived as important by respondents. The RII formula indicates that;

$$
\text { RII }=\frac{\sum I T}{. t * V}
$$

Where, $\mathrm{W}$ is weight given to each statement by the respondents and ranges from 1 to 10; A representing the Higher response integer and $\mathrm{N}$ is the total number of respondents.

\section{Analysis on QOL}

From the literature, 9 main components were identified. Then, all the factors associated with the QOL components were calculated using the relative importance index (RII) equation above. In this study, the RII was used to compare and rank each of QOL components based on the degree of frequency and severity of respondents' preferences over the same scales. Result of the RII analysis is shown in Table 2 below.

Table 2: RII of QOL components

\begin{tabular}{llll}
\hline No. & QOL Components & RII & Rank \\
\hline & 1) Economic Capacity & & \\
\hline 1. & Current job/occupation & 0.662 & 1 \\
2. & Amount of current household income & 0.616 & 2 \\
3. & Cost of commuting every month & 0.608 & 3 \\
4. & Amount of personal monthly income to live comfortable life & 0.591 & 4 \\
5. & Ability to buy/own properties & 0.390 & 5 \\
\hline & 2) Transportation Capacity & & \\
\hline 1. & Owned transport & 0.841 & 1 \\
2. & Often use public transportation in daily life & 0.380 & 2 \\
3. & Preference on using public transportation for daily activities & 0.360 & 3 \\
\hline & 3) Living Condition & & \\
\hline 1. & Current living place & 0.739 & 1 \\
2. & Neighbouring with foreigners & 0.551 & 3 \\
3. & Strategic location of current house & 0.654 & 2 \\
4. & Provision of facilities for PWDs & 0.419 & 4 \\
\hline & 4) Environment & & \\
\hline 1. & Air quality & 0.742 & 2 \\
2. & Water quality and provision & 0.751 & 1 \\
3. & Crowding and noise level & 0.657 & 4 \\
4. & Protection and preservation of natural elements & & 6
\end{tabular}


PLANNING MALAYSIA

Journal of the Malaysia Institute of Planners (2018)

5. Overall landscape $\quad 0.644 \quad 5$

6. Overall cleanliness $\quad 0.715 \quad 3$

\begin{tabular}{|c|c|c|c|}
\hline & 5) Social involvement & & \\
\hline 1. & Social interaction with residents of the neighbourhood & 0.627 & 3 \\
\hline 2. & Support from neighbours & 0.631 & 2 \\
\hline 3. & Interracial relation & 0.664 & 1 \\
\hline 4. & $\begin{array}{l}\text { Involvement in club/association in neighbourhood/ work } \\
\text { place }\end{array}$ & 0.527 & 5 \\
\hline \multirow[t]{2}{*}{5.} & Overall satisfaction with interactions & 0.590 & 4 \\
\hline & 6) Public safety & & \\
\hline 1. & Safe walking alone in neighbourhood in day time & 0.787 & 1 \\
\hline 2. & Safe walking alone in neighbourhood at night time & 0.653 & 6 \\
\hline 3. & Availability of police protection for 24 hours & 0.674 & 4 \\
\hline 4. & Presence of fire bridges for 24 hours & 0.655 & 5 \\
\hline 5. & Provision of street lighting in neighbourhood & 0.746 & 2 \\
\hline \multirow[t]{2}{*}{6.} & Overall satisfaction with safety condition & 0.723 & 3 \\
\hline & 7) Health and physical well-being & & \\
\hline 1. & Satisfaction on health condition & 0.841 & 1 \\
\hline 2. & Feel energetic waking up every morning & 0.782 & 4 \\
\hline 3. & Require monthly/weekly/daily check-up & 0.485 & 7 \\
\hline 4. & Have enough sleep everyday (7-9 hours) & 0.738 & 5 \\
\hline 5. & Physical health allows me to perform daily activities & 0.806 & 3 \\
\hline 6. & $\begin{array}{l}\text { Never experience unstable mood such as despair, depression, } \\
\text { anxiety in a week }\end{array}$ & 0.721 & 6 \\
\hline \multirow[t]{2}{*}{7.} & Comfortable with physical appearance & 0.811 & 2 \\
\hline & 8) Daily activities & & \\
\hline 1. & Always plan my daily activities & 0.577 & 2 \\
\hline 2. & Regularly recorded daily activities & 0.399 & 5 \\
\hline 3. & Always do beneficial activities & 0.635 & 1 \\
\hline 4. & Regularly plan my activities a week beforehand & 0.476 & 3 \\
\hline \multirow[t]{2}{*}{5.} & Regularly plan any activities a month before hand. & 0.446 & 4 \\
\hline & 9) Educational Satisfaction Level & & \\
\hline 1. & Satisfaction on current educational background & 0.710 & 2 \\
\hline 2. & Intend to further study to another level & 0.608 & 4 \\
\hline 3. & $\begin{array}{l}\text { Always supportive if children, spouse or siblings intend to } \\
\text { further study at another level }\end{array}$ & 0.919 & 1 \\
\hline \multirow[t]{3}{*}{4.} & Malaysia's educational system generate students with ideas & 0.685 & 3 \\
\hline & Overall satisfaction & & \\
\hline & In general, how much do you enjoying your life? & 0.771 & 1 \\
\hline
\end{tabular}


Noor Suzilawati Rabe, Mariana Mohamed Osman, Syahriah Bachok, Nur Farhanah, \& Mohammad Faris Abdullah

Perceptual Study on Conventional Quality of Life Indicators

Generally, results in the Table 2 show that majority of the respondents were likely to perceive QOL components as moderate and highly satisfied. Among the 9 components, the highest RII value is 0.919 ranked representing the component related to educational satisfaction level. Meanwhile, the lowest RII value is 0.360 indexes on satisfaction towards the respondents' preference in using public transportation for daily activities.

For economic capacity aspect of QOL, most of the respondents ranked satisfaction on current job as the highest with RII of 0.662 , while majority of them were likely felt dissatisfied with ability to own or purchase properties (RII=0.390). On the other hand, majority of respondents were likely to be satisfied with the water quality (RII=0.751) and air quality in their neighbourhood (RII= 0.742). However, QOL aspect on the protection and preservation of natural elements was ranked as the lowest with RII only 0.637 . This shows that there is an issue perceived by respondents related on the environmental protection and preservation matters.

Contrarily, there was a high RII value of 0.787 on QOL safety component related to safe walking alone in neighbourhood in day time. This is followed with respondents moderate and high satisfaction on the provision of street lighting to prevent crime $(\mathrm{RII}=0.746)$ and satisfaction on safety condition in the neighbourhood (RII=0.723). On matter related to health, most of the respondents were likely felt satisfied with their current health condition (RII=0.841), and comfortable with their physical appearance $(\mathrm{RII}=0.811)$.

Overall, respondents claimed that they were satisfied and enjoying their life (RII=0.771) and at the same time satisfied with their current quality of life with RII of 0.742 representing by indexes greater than 0.5 . In addition, the results suggested that improvement on respondents' environment including health status (RII=0.841), education level (RII=0.710), safety elements (RII=0.723), transportation $(\mathrm{RII}=0.841)$ and income $(\mathrm{RII}=0.616)$ literally had positive impact on respondents QOL satisfaction level. The results indirectly showed that each of QOL components was interrelated with each other in creating the satisfaction on quality of life of people. This is in line with the findings on the three basic human relationships with Allah SWT, with other human as well as with nature in protecting their faith (din), human self (nafs), intellect ( $a q l$ ), posterity (nasl) and wealth ( $\mathrm{mal}$ ) through establishing justice, eliminating prejudice and alleviating hardship by promoting goods and preventing harm to self and others.

Scientifically, the interrelationship of human development and the quality of life is proven to affect not only human physical development, but also human development and social health (Kilimova, 2016). However, QOL being a complex matters and addition to the growing theories and approaches to measure 
human well-being has making it imperative to improve the lives of population as a whole.

Malaysia goal to achieve foster in sustainable economic well-being encountered weakness in several areas including educational attainment and skills mainly on labour productivity growth, personal earnings as well as healthcare particularly on healthy life expectancy and access to quality medical services. This requires policy makers, professionals and related stakeholders to further increase the quality and sustainability of development in addressing areas of social protection, education, clean energy and inclusive growth (OECD, 2016).

Studies by numerous authors (Abdul Razak, Hamid \& Ya'kob, 2013, Mohamad et al., 2014) that focus on QOL found that Maslow's hierarchy of needs has failed to completely cover and fulfil the measurement required for quality of life. Thus, this is where the combination of policy, objectives and goal of life with the divine Islamic law would be essentials to fill in the huge gap in measuring not only the needs and wants aspects but also subjective measurement of the quality of life that deals with the feeling of happiness and individual satisfaction with life.

Nevertheless, adequate attention in addressing a suitable approach to measure quality of life as well as in defining what directly and indirectly constitutes quality of life is important. Inappropriate measures and incorrect information would mislead the authorities to identify the significant aspects of quality of life that should be given more attention in order to improve the quality of life of the people as a whole.

\section{CONCLUSION}

In summary, all the five components of maqasid al-shariah are interrelated in creating balance and promoting well-being to human life. Through the integration of the maqasid al-shariah components in the measurement of quality of life in Malaysia, the needs and wants of the people can be achieved. The concept of maqasid al-shariah has the dimension of individual, community, and the creator and this clearly shows that a person's is accountable on his/her action to the creator, to him or herself and finally to the other people effected by the actions. Therefore, it is hoped that an effective and inclusive measure of QOL could be strengthened to promote for more harmonise and sustainable well-being. 
Noor Suzilawati Rabe, Mariana Mohamed Osman, Syahriah Bachok, Nur Farhanah, \& Mohammad Faris Abdullah

Perceptual Study on Conventional Quality of Life Indicators

\section{REFERENCES}

Abdullah, S., \& Furqani, H. (2012, October). The objectives of shariah (maqasid syariah) in takaful: Highlighting the noble practice. In International Conference on Management, Economics \& Finance. October 15-16, 2012, Kuching, Malaysia.

Abdul Razak, D., Ab. Hamid, S. N., \& Ya'kob, S. A. (2013). Needs and wants theory: A comparison between Maslow's hierarchy of needs and maqasid al shariah. In 10th Asian Academy of Management. August 23-25, 2013, Penang, Malaysia.

Chapra, M. U. (1993). Islam and economic development. Islamabad: International Institute of Islamic Thought \& Islamic Research Institute.

Costanza, R., Fisher, B., Ali, S., Beer, C., Bond, L., ... \& Snapp, R. (2005). Quality of life: An approach integrating opportunities, human needs, and subjective wellbeing. Ecological Economics, 61(1), 267-276.

Diener, E., Suh, M., Lucas, E., \& Smith, H. (1999). Subjective well-being: Three decades of progress. Psychological Bulletin, 125(2), 276-302.

Dusuki, A. W., \& Abdullah, N. I. (2007) Maqasid al-syariah, maslahah and corporate social responsibility. The American Journal of Islamic Social Science., 24(1), 25-45.

Gilgeous, V. (1998). The quality of work life. Integrated Manufacturing System, 9(1), $173-181$

Hanapi, M. S. (2015, July). The Islamic-Based Development Index (IBD-I) worldview: A case of the Malaysian Syariah Index (MSI). In 1st Asia Pacific Conference on Advanced Research (APCAR-2015). July 23-24, Adelaide, Australia.

Ibrahim, N., Din N. C., Ahmad, M., Ghazali, S. E., Said, Z., Shahar, S., ..., Razali, R. (2013). Relationships between social support and depression, and quality of life of the elderly in a rural community in Malaysia. Asia-Pacific Psychiatry, 5(1), 59-66.

Idris, K., Mohamed Shaffril, H. A., Md. Yassin, S., Abu Samah, A., Hamzah, A., Abu Samah, B. (2016). Quality of life in rural communities: Residents living near to Tembeling, Pahang and Muar rivers, Malaysia. PLOS ONE, 11(3): e0150741.

Kilimova, L. (2016). Quality of life as a human development determinant in the context of economic instability. Economic Annals-XXI, 157, 59-62.

Mohamad, M., Mat Ali, N. A., Mohamad, N., Wan Chik, W. Y., Muhammad, N., Karim, F. (2014). Kualiti hidup pendekatan maqasid syahriah. Kuala Terengganu, Terengganu: Universiti Sultan Zainal Abidin Publisher

Mohit, M. A. (2014). Present trends and future directions of quality of life. Procedia Social and Behavioral Sciences, 153, 655-665.

Noll, H. H. (2002). Social indicators and quality of life research: Background, achievements and current trends. In N. Genov (Ed.) (2002), Advances in sociological knowledge over half a century. Paris: International Social Science Council.

Omar, D. (2009). Assessing residents' quality of life in Malaysian new towns. Asian Social Science, 5(6), 94-102.

Organisation for Economic Co-operation and Development [OECD] (2016). OECD economic surveys: Malaysia economic assessment. Retrieved from http://www.oecd.org/eco/surveys/economic-survey-malaysia.htm

Pajaziti, A. (2014). Transition education and quality of life. Procedia - Social and 
PLANNING MALAYSIA

Journal of the Malaysia Institute of Planners (2018)

Behavioral Sciences, 11, 4737-4741.

Phillips, D. (2006). Quality of life: Concept, policy and practice. London: Routledge.

Skevington, S. M. (2010). Qualities of life, educational level and human development: An international investigation of health. Social Psychiatry Psychiatr Epidemiol, 45(10), 999-1009.

Syed Ali, S. \& Hassan, H. (2014). Towards a maqasid al-shariah based development index, IRTI Working Paper Series WP\# 1435-18. Saudi Arabia: Islamic Research and Training Institute.

United Nations Development Programme [UNDP] (2016). Human development report 2016. Washington DC: Communications Development Incorporated.

Wahbah Al-Zuhaily. (1994). Al- wajiz fi usul al-figh. Damsyik: Dar Al-Fikr.

Yahya, A. S., \& Selvaratnam, D. P. (2015, April). Relationship between Malaysian quality of life and gross domestic product. Kuala Lumpur International Business, Economics and Law Conference. April 18-19, 2015, Kuala Lumpur, Malaysia.

Yamane, T. (1967). Statistics, an introductory analysis. New York: Harper and Row.

Yassin, S. M., Mohamed Shaffril, H. A., Hassan, M. S., Othman, M. S., Abu Samah, B., Abu Samah, A., \& Ramli, S. A. (2012). The quality of life and human development index of community living along Pahang and Muar Rivers: A case of communities in Pekan, Bahau and Muar. Journal of Sustainable Development, 5(6), 90-103.

Yusuf al-Qaradawi (2011). Fiqh al-Zakah (Monzer Khaf, Trans.). Kuala Lumpur: Islamic Book Trust.

Zainal, N. R., Kaur, G., Ahmad, N. A., \& Khalili, J. M. (2012). Housing conditions and quality of life of the urban poor in Malaysia. Procedia - Social and Behavioral Sciences, 50, 827-838. 